\title{
Leveraging the Use of Social Media in Teaching Writing: A Qualitative Investigation among ESL Pre-Service Teachers
}

\author{
https://doi.org/10.3991/ijim.v13i11.10910 \\ Rusreena Rusli, Harwati Hashim ${ }^{(凶)}$, Melor Md Yunus, \\ Nur Yasmin Khairani Zakaria, Helmi Norman \\ Universiti Kebangsaan Malaysia, Cheras, Malaysia \\ harwati@ukm.edu.my
}

\begin{abstract}
Advances of technology and innovation suggest new form and paths in language teaching. Social media use can be a great influence for English as a Second Language (ESL) students especially in writing competency. Despite of many positive findings that reported the affordances in social media use, there are still insufficient studies that investigate ESL pre-service teachers' perception on this matter. Hence, this study was conducted to explore ESL preservice teachers' views upon leveraging the use of social media in teaching of writing focusing on the opportunities and challenges in terms of how they perceived the usefulness and ease of use. This study employed qualitative methods where thirty-four ESL pre-service teachers from a public university were involved. Based on the findings, it can be concluded that ESL pre-service teachers perceived the use of social media in teaching writing can be of beneficial and similarly challenging. Opportunities stated by the participants include enhancement in collaborative learning, supporting students' self-directed learning and simplify the teaching and learning processes. On the other hand, the challenges mentioned by the participants are that social media can be a source of distraction, deterioration in language and plagiarism. Thus, it is advisable that teachers play their roles responsibly in managing students' activities online and also be equipped with technology skills to enhance the establishments of social media in ESL teaching of writing.
\end{abstract}

Keywords - Challenges, opportunities, social media, teaching of writing, TESL pre-service teachers

\section{Introduction}

The fusion of technology into the present language teaching and learning is influenced by the requirements of millennial students who are especially interested and attracted by technological use [1] [2] [3]. In connection to that, there have been changes in the ESL in-training teachers' programme where its main goals and objectives are to increase the quality of future teachers in line with the digital progress. With the current needs of shaping 21 st-century classroom in schools, the use of tech- 
nology has now become compulsory for teachers to incorporate in the classroom [4]. In this millennial, all Gen Z students are a part of the digital tools' world [5] [6] [7]. Thus, effectiveness of learning can be enhanced by using technology in class [8]. Digital tools obviously offer access to social media networking which is an incredible platform by itself to saddle in the classroom as a device for enhancing communication in classrooms [9]. The web is inundated with researches that overviews the indistinguishable association among students and technology. Social media can be a platform where students are urged to utilise their creativity to fortify their composition. Nevertheless, [10] claimed that the use of social media is still debatable as whether or not it is a required step explicitly for students' writing enhancements in language classrooms. [11] also stated that it was an oddity that there was little practice of social media in writing classrooms in Malaysia. Furthermore, [12] stated that there is little research on faculty involvement in social media implementation based on students' writing performances.

It is crucial to have major support from the faculty and management team on social media implementation in ESL writing classes to make sure proper establishments of the conduction. Besides that, the major gap identified from the past literatures showed that many studies were conducted based on the students and ESL teachers [13] [14]. There are insufficient studies that focused on the ESL pre-service teachers' and their perceptions towards social media implementation in ESL writing classes. Therefore, this study aimed to bridge the gap by investigating the perceptions of ESL pre-service teachers towards the social media use in ESL writing classrooms. This study focused on collecting their views towards the opportunities and challenges in using social media in teaching writing skills. This research is pointed to answering these two questions notably; (i) What are the perceived opportunities of using social media in teaching ESL writing in terms of perceived usefulness and ease of use? (ii) What are the perceived challenges of using social media in teaching ESL writing?

\section{$2 \quad$ Literature Review}

\subsection{Social media and language learning}

Researchers have demonstrated different meanings of social media, yet most conceptualizations clarify social media as a path for individuals to keep up with current news, to make new associations, to make and share their very own content and in some degree, to make their own content visible and follow-able to other people [16]. Regardless of the various meanings, most people utilise social media usually for entertainment, social collaboration, to look for data, and to pass their leisure time [17]. Many past researchers demonstrated that various students are showing positive improvements by social media implementation in conducting writing classes [13]. There are huge advantages especially for students, towards this dependence on social media networking. Students who use social media may frame more prominent quantities of connections that enable them to construct social capital [18] and subsequently structure their foundation that can affect their future study in higher level. Students are 
more interactive both online and offline. Access to social media networks may enable students to trust that they have the chances to get help from many sources through the sites even though the sites are not explicitly used for academic purposes [18] [19] [20]. [21] stated that social media networking also can possibly be utilized in a learning situation as it advances psychological commitment of students in class and along these lines their scholarly execution and achievement.

\subsection{Teachers' feedback in ESL teaching and learning}

In the early age of network advances, students frequently reported of feeling isolated or less involved in their own learning progresses. When social media emerged, whatever they tweet, post, or like can be shared online. Subsequently, it is vital for ESL teachers to guarantee that students get feedback on the content that they make and offer, especially in early stages in a writing course [22]. Unfortunately, it is frequently not practical for the teacher to give sufficient feedback to each student in a large class. Therefore, it is imperative to connect all students by motivating them to give feedback on their peers' works. Students can even get responses from other experts in their network community to expand their feedback input. This is also supported by [23] that both giving and accepting criticism prompted visible upgrades in students' writing performances. The sufficient feedback given will positively change the students' perception and they are proven to work willingly upon their received feedback.

\section{$3 \quad$ Methodology}

Theoritically, this study is grounded by the Technology Acceptance Model [24]. The adapted model for this study is as presented in Figure 1 below.

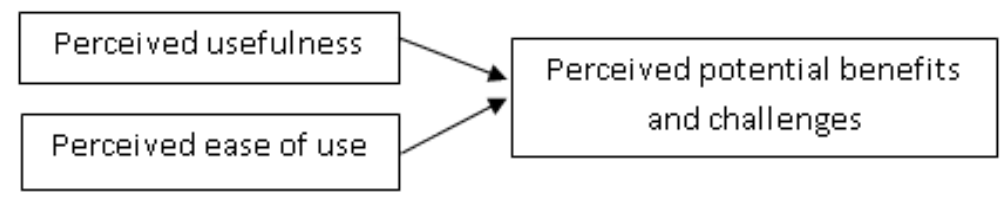

Fig. 1. Framework adapted from Technology Acceptance Model [24]

Referring to Figure 1, perceived usefulness speaks to profitable possible outcomes whether physiological or sociological that can be achieved from the traits of the technology utilized. Meanwhile, the idea of perceived ease of use identifies a standard of minimum effort that expresses that every student will adopt a course of activity that will only use the least average work from the student. This rule of least effort can be stretched out to foresee that the social media user will be progressively keen to learn the application features, make utilization of the applications and willing to perform online activities on social media sites for example, transferring and sharing video or doing networking activities. Perceived ease of use implies the degree to which a tech- 
nology is seen not to be hard to comprehend, learn, or work with. With regards to social media, the students may evaluate the site depending on how easy it is to be utilized and how beneficial it is in helping them to achieve their learning goals.

In order to answer the research questions, this study employed qualitative method that concentrated on reflective writing to require data on how the ESL pre-service teachers perceived social media use in instructing ESL writing classes. The reflective writing focuses on the perceived opportunities and perceived challenges in teaching ESL writing in terms of perceived usefulness and ease of use. With this method, students can intentionally interface their thoughts, ideas, feelings and experiences into written words. This method is particularly important as the data given through this strategy may incorporate significant and genuine reflection of the ESL pre-service teachers. The participants include thirty-four students aged between 20-23 years old from a public university, who are taking a TESL degree programme. The data were analysed using thematic analysis in identifying the patterns (themes) and are presented in the following sections.

\section{$4 \quad$ Results and Discussion}

\subsection{Opportunities of social media use in teaching writing: Perceiving usefulness and ease of use}

In terms of usefulness of using social media in teaching writing, the ESL preservice teachers believed that social media brought many benefits in students' writing skills. One of the benefits, popularly stated by the participants is the ability of conducting collaborative learning in writing classes. Collaborative learning in writing can occur when the students use social media to find and share information in their community, look online into activities for English writing and assemble references for writing tasks. Collaborative learning also can occur when the students are exchanging posts and comments which helped them to practice and improve their writing skills. The followings are among the responses given by the participants.

"Social media focuses on collaborative and cooperative learning. The learners collaborate in giving opinions on comments section, share documents or link their status with other friends." (Participant 1)

"Students not only learn from their teachers but they also able to learn from other people." (Participant 5)

From the responses, it is shown that the pre-service teachers believed that social media could be used for colloaborative and cooperative learning. The findings are in line with [12] that social media allows the students to write in different settings where they can connect what is instructed at school and use it in authentic situation, thus enhancing their writing performances. Moreover, collaborative learning can help lower proficiency students to connect with their peers and have open discussion on given writing tasks. The use of social media network in writing classroom produces different learning environments for the students. This is also supported by [25] who reported that discussion is very important in language learning where students can 
learn and gain from their peers. Collaborative learning also prompted to fortify the role of the students' motivation by promoting the value of group work and thus initiated communication and interaction skills [26].

Other than that, the participant shared that social media use in teaching writing can encourage students to have self-directed learning. As cited from some of the participants;

"I could suggest English learning pages to be followed by students. This site will improve my students' understanding and encourage them to be self-directed in learning. " (Participant 3)

"Students are exposed to new things, hence they acquired ideas for their writing tasks. This will also help the students to familiarize themselves to the writing activities." (Participant 18)

From the findings, self-directed learning from the use of social media enables students to learn by their very own instead of just taking instruction from the teachers. Consequently, social media use in teaching writing skills includes the ability of students to choose independently about what and to what degree a student can learn, need and how they can achieve their learning aims with their chosen sources. Students can expand their interest in writing and utilizing information from online exercises, which was mediated in a positively encouraged medium in social media platforms [27]. Self-directed learning via social media integration helps the students to become familiar with the language usage and there is positive correlation between the frequency of social media usage and the increase in students' confidence level [28]. There are countless learning materials and resources which can be utilized for students [30].

Additionally, the participants also pointed out social media use in teaching writing helps to ease the teaching processes. The followings are some of the responses given by the participants:

"Social media can be used as a substitute for an online learning system where teachers can easily upload tasks and notes to everyone." (Participant 15)

"Social media can help the teachers to assess the students' progress and achievement in writing. Furthermore, social media helps to release teachers' burden as there are many applications in social media that can be used to check students' writing." (Participant 22)

In terms of ease of use, the findings demonstrate that the act of utilizing technology would decrease the expense for preparing lessons. At present, teachers would need to spend time and energy to think of creative activities to attract students' attention. By means of digital tools, teachers can decrease their workload in conducting lessons such as less paper to mark by having tasks set online. Through online learning, teachers would have the required tool to monitor students and their progress online [30]. The findings also support the study by [31] who stated that learning through digital tool enhance their ESL learning where they find it easier to find translation of difficult words and to discover new vocabulary. Social media also helps to increase students' IT aptitudes and create creativity in writing, promote students to have comfortable and enjoyable writing lessons [32]. 
4.2 Challenges of social media use in teaching writing: When the ease become hindrance

The primary challenge due to the ease of use of social media in teaching writing as pointed by the participants is that the sites may become a distraction for the students and this could prevent students to focus and take part fully on the lesson or tasks. This is also supported by [33] which reported in their study how some students may forget to complete their writing task when they had too much fun in social media. A study by [32] also reported that some students demonstrated their concern on their distraction towards social media and online games.

Based on the findings, the participants trusted that it was vital for them to remain focus and to stay away from diversions when learning using social media. As stated by some of the participants;

"Students might use social media during writing activity and this can be a potential distraction for the students." (Participant 18)

"It can cause students to have short attention span and lack of focus in class." (Participant 26)

Besides that, participants also admitted the existence of problems like usage of informal language and deterioration in grammar in formal writing. The utilization of these short forms, incomplete sentences and internet language may cause the students negatively as they may affect their academic writing during tests and examinations at school. Although there are some platforms and sites that can help the students to make writing corrections such as spellings and sentence structure, this can cause the students to get used to the constant help and to have an easy way out. Thus, students will not have the chances to learn and improve by their mistakes or even do not realize what the mistakes are. Students' writing may also result in negative patterns concerning vocabulary, grammar and spelling since they depend too much on the correction tools [32].

Apart from that, there is no guarantee that the internet will provide correct answers and this will confuse and directed students to the wrong path in language. As cited by some of the participants;

"Communicating through social media inevitably promote wrong usage of standard English and also, short forms and abbreviations." (Participant 9)

"Social media can cause deterioration in students' writing skills in terms of spelling, grammar and lexical structures." (Participant 33)

Another worry raised by the students was about the possibility of plagiarism by which students can easily copy other people work from online sources without proper citation to the writer. As mentioned by some of the participants;

"Plagiarism will absolutely happen. Whether they copy any answer in the social media or they ask their friends to give them answers." (Participant 8)

"...students may simply copy all the information first. The student may believe wrong information or share it with other people." (Participant 27)

In a nutshell, the findings depict that in some situations, the presence of a teacher is still crucial. The findings support the claimed made by [32] that students required 
their teachers' guidance in term of writing. Thus, there is a need to look into this matter if technology needs to be embedded in teaching and learning [34] [35].

\section{Conclusion and Implication}

Overall, the findings of this study contribute to the vast research conducted on the use of social media in teaching and learning. This study looked into the perspectives of the ESL pre-service teachers who are going to be teaching in the next few years in school. It is crucial to look into how these ESL pre-service teachers perceived the benefits and challenges of using social media in teaching writing as this would be the demand of the teaching approach among the new generation of learners. This study conclude that online learning will influence and shape the teaching and learning of future students. The use of social media in ESL writing is both beneficial and challenging. Opportunities in using social media include enhancing collaborative learning, promote self-directed learning and ease teaching and learning process in writing classrooms. Meanwhile, the challenges in social media use are that it can be a distraction for students, improper language used and possibility to plagiarism. Therefore, proper management is crucially needed to implement social media in teaching of writing. Teachers need to properly distribute their time and commitment to go through students' online works as so to increase students' motivation in writing. The accomplishment of social media use in ESL writing is dependent upon a conducive learning condition and a responsible teacher who is willing to try and accept error of new way in teaching that past the limits of traditional classroom. The time has come for our language teachers to start changing their teaching approaches in line with current technology in order to stay aware of the demands for the generation $Z$ students. In the future, it may be worth studying the use of artifial intelligence as autonomous tutors/teachers or bots as well as other future technologies in ESL learning. Subsequently, it is suggested that pre-service teachers are trained to design their teaching of writing lessons with the help of social media. In the future, it is recommended that studies to be conducted on looking at the learning analytics of using social media for teaching and learning writing as to ensure the effectiveness and sustainability of the teaching approach.

\section{Acknowledgement}

This research is supported by Universiti Kebangsaan Malaysia under research scheme no

- KRA-2018-044

- GG-2019-017. 


\section{$7 \quad$ References}

[1] Azli, W. U. A. W., Shah, P. M., \& Mohamad, M. (2018). Perception on the Usage of Mobile Assisted Language Learning (MALL) in English as a Second Language (ESL) Learning among Vocational College Students. Education, 9, 84-98. https://doi.org/10.4236/ce.2 $\underline{018.91008}$

[2] Bowser, A., Hansen, D., He, Y., Boston, C., Reid, M., Gunnell, L., \& Preece, J. (2013, October). Using gamification to inspire new citizen science volunteers. In Proceedings of the first international conference on gameful design, research, and applications (pp. 18-25). ACM. https://doi.org/10.1145/2583008.2583011

[3] Hashim, H., Yunus, M. M., \& Embi, M. A. (2018). Factors influencing polytechnic English as second language (ESL) learners' attitude and intention for using mobile learning. Asian ESP Journal, 14(7), 195-208. https://doi.org/10.4236/ce.2016.78119

[4] Lim, P.R. \& Md Noor, Norah. (2019). Digital Storytelling as a Creative Teaching Method in Promoting Secondary School Students' Writing Skills. International Journal of Interactive Mobile Technologies (iJIM). Vol 13, No 07. https://doi.org/10.3991/ijim.v13i07.107 $\underline{98}$

[5] Geck, C. (2007). The generation Z connection: Teaching information literacy to the newest net generation. Toward a 21st-Century School Library Media Program, 235, 2007.

[6] Garcia, R. C. (2018). The Role of Information and Communication Technology in Secondary Schools (Doctoral dissertation).

[7] Hope, J. K. (2019). Could educational technology replace traditional schools in the future?. In Advanced Methodologies and Technologies in Modern Education Delivery (pp. 252262). IGI Global. https://doi.org/10.4018/978-1-5225-7365-4.ch021

[8] Soh, H.M., Abdullah, A.H., Mokhtar, Mahani., Ali, D.F., Jumaat, N.F., Ashari, M. \& A.S., Norazrena. (2019). Active Learning Using Digital Smart Board to Enhance Primary School Students' Learning. International Journal of Interactive Mobile Technologies (iJIM). Vol 13, No 07. https://doi.org/10.3991/ijim.v13i07.10654

[9] Nurul Farhana Jumaat, Noriesah Ahmad, Norazrena Abu Samah, Zakiah Mohamad Ashari, Dayana Farzeeha Ali, Abdul Halim Abdullah. (2019). Facebook as a Platform of Social Interactions for Meaningful Learning. International Journal of Emerging Technologies in Learning. Vol 14, No 04. https://doi.org/10.3991/ijet.v14i04.9363

[10] Kaufer, D., Gunawardena, A., Tan, A., \& Cheek, A. (2011). Bringing social media to the writing classroom: Classroom salon. Journal of Business and Technical Communication, 25(3), 299-321. https://doi.org/10.1177/1050651911400703

[11] Razak, N. A., Saeed, M., \& Ahmad, Z. (2013). Adopting Social Networking Sites (SNSs) as Interactive Communities among English Foreign Language (EFL) Learners in Writing: Opportunities and Challenges. English Language Teaching, 6(11), 187-198. https://doi.or g/10.5539/elt.v6n11p187

[12] Vie, S. (2015). What's going on?: Challenges and opportunities for social media use in the writing classroom. The Journal of Faculty Development, 29(2), 33-44.

[13] Gao, Y. (2019). An Analysis of Social Media Use Within and Outside of College English Classes in China.

[14] Yunus, M. M., Salehi, H., \& Chenzi, C. (2012). Integrating social networking tools into ESL writing classroom: Strengths and weaknesses. English Language Teaching, 5(8), 4248. https://doi.org/10.5539/elt.v5n8p42

[15] Treem, J. W., Dailey, S. L., Pierce, C. S., \& Biffl, D. (2016). What we are talking about when we talk about social media: A framework for study. Sociology Compass, 10, 768784. https://doi.org/10.1111/soc4.12404 
[16] Whiting, A., \& Williams, D. (2013). Why people use social media: A uses and gratifications approach. Qualitative Market. https://doi.org/10.1108/qmr-06-2013-0041

[17] DeAndrea, D. C., Ellison, N. B., LaRose, R., Steinfield, C., \& Fiore, A. (2012). Serious social media: On the use of social media for improving students' adjustment to college. The Internet and Higher Education, 15(1), 15-23. https://doi.org/10.1016/j.iheduc.2011.05. $\underline{009}$

[18] Gabarre, S., Gabarre, C., Din, R., Shah, P., \& Karim, A. A. (2016). Addressing foreign language learning anxiety with Facebook. Creative Education, 7(01), 93. https://doi.org/10. $\underline{4236 / \text { ce. } 2016.71010}$

[19] Ng, L. S., Thang, S. M., \& Noor, N. M. (2018). The Usage of Social Networking Sites for Informal Learning: A Comparative Study Between Malaysia Students of Different Gender and Age Group. International Journal of Computer-Assisted Language Learning and Teaching (IJCALLT), 8(4), 76-88. https://doi.org/10.4018/ijcallt.2018100106

[20] Alshuaibi, M. S. I. I. (2015). Use of social media, student engagement, and academic performance of business students at Universiti Utara Malaysia (Doctoral dissertation, Universiti Utara Malaysia). https://doi.org/10.17576/jkmjc-2016-3201-18

[21] Anderson, T. (2016). Theories for learning with emerging technologies. Emergence and innovation in digital learning: Foundations and applications, 35-50.

[22] Huisman, B., Saab, N., van Driel, J., \& van den Broek, P. (2018). Peer feedback on academic writing: undergraduate students' peer feedback role, peer feedback perceptions and essay performance. Assessment \& Evaluation in Higher Education, 43(6), 955-968. https:// doi.org/10.1080/02602938.2018.1424318

[23] Braun, V., \& Clarke, V. (2006). Using thematic analysis in psycholo-gy. Qualitative research in psychology, 3(2), 77-101.

[24] Davis, F. D. (1989). Perceived Usefulness, Perceived Ease of Use, and User Acceptanc- e of Information Technology," MIS Quarterly (13:3). https://doi.org/10.2307/249008

[25] Goodwin, R. (2018). Language Proficiency and Students Behavior in the Classroom: A Comparative Study. MODERN JOURNAL OF LANGUAGE TEACHING METHODS, 8(1), 91-103.

[26]Abdullah, M. Y., Hussin, S., \& Shakir, M. (2018). The Effect of Peers' and Teacher's EFeedback on Writing Anxiety Level Through CMC Applications. International Journal of Emerging Technologies in Learning (iJET), 13(11), 196-207. https://doi.org/10.3991/ijet.v $\underline{13 i 11.8448}$

[27]Ibatova, A. Z. (2018). Creating A Positive Climate: A Didactic Resource For English Language Assessment. MODERN JOURNAL OF LANGUAGE TEACHING METHODS, 8(3), 463-470.

[28]Abrahim, S., Mir, B. A., Suhara, H., \& Sato, M. (2018). Exploring Academic Use of Online Social Networking Sites (SNS) for Language Learning: Japanese Students' Perceptions and Attitudes Towards Facebook. J Inform Tech Softw Eng, 8(223), 2. https://doi.o $\mathrm{rg} / 10.4172 / 2165-7866.1000223$

[29] Moradi, H. (2018). Self-directed Learning in Language Teaching-learning Processes. www.mjltm.com info@mjltm.org, 59.

[30] Mustafa, N., Nordin, N. M., Embi, M. A., \& Norman, M. H. (2018). Testing the Usability of a Mobile Learning Module. International Journal of Engineering \& Technology, 7(4.21), 113-117.

[31] Hashim, H., Yunus, M. M., \& Embi, M. A. (2018). Learning Through Mobile: Exploring the Views of Polytechnic ESL Learners. Teaching and Learning English in Multicultural Contexts (TLEMC), 2(1). 
[32] Mohamad, M., Ghazali, N., \& Hashim, H. (2018). Secondary School Students' Perceptions on the Use of Google+ towards Improving ESL Writing Skills. International Journal of Emerging Technologies in Learning (iJET), 13(09), 224-238. https://doi.org/10.3991/ije t.v13i09.8479

[33] Aghajani, M., \& Adloo, M. (2018). The Effect of Online Cooperative Learning on Students' Writing Skills and Attitudes through Telegram Application. International Journal of Instruction, 11(3), 433-448. https://doi.org/10.12973/iji.2018.11330a

[34] Sukri, S. I. A., \& Yunus, M. M. (2018). Revitalising English Teacher Education through Blended Learning: A Boon or Bane?. International Journal of Engineering \& Technology, 7(4.21), 97-101.

[35] Zaki AA, Md Yunus M. Potential of mobile learning in teaching of ESL academic writing. English Language Teaching. (2015). May 28;8(6):11-19. Available from, https://doi.org/10 $.5539 /$ elt.v8n6p11

\section{Authors}

Rusreena Rusli is a master's student at the Faculty of Education, National University of Malaysia (UKM).

Harwati Hashim is a Senior Lecturer/Assistant Professor at the Centre of Teaching and Learning Innovations, Faculty of Education, Universiti Kebangsaan Malaysia (UKM).

Melor Md Yunus is an Associate Professor at the Faculty of Education, Universiti Kebangsaan Malaysia and is currently the Deputy Dean (Research and Innovation) at the Faculty of Education, Universiti Kebangsaan Malaysia (UKM).

Nur Yasmin Khairani Zakaria is a young lecturer at the Department of Teaching and Learning Innovations,vFaculty of Education, Universiti Kebangsaan Malaysia.

Helmi Norman is the assistant dean for teaching and learning at the Centre of Teaching and Learning Innovations, Faculty of Education, Universiti Kebangsaan Malaysia (UKM).

Article submitted 2019-05-22. Resubmitted 2019-07-25. Final acceptance 2019-07-27. Final version published as submitted by the authors. 